\title{
Adherence of Streptococci to Surface-modified Glass
}

\author{
By N. SATOU,${ }^{*}$ J. SATOU,${ }^{1}$ H. SHINTANI ${ }^{1}$ AND K. OKUDA ${ }^{2}$ \\ ${ }^{1}$ Department of Operative Dentistry and ${ }^{2}$ Department of Biochemistry, Hiroshima University, \\ School of Dentistry, Hiroshima 734, Japan
}

(Received 8 June 1987; revised 16 December 1987)

Four types of surface-modified glass were prepared. Aminopropyl glass was prepared by alkylsilylation of glass slides with $\gamma$-aminopropyltriethoxysilane. This glass carries primary amino groups which may be protonated at $\mathrm{pH} 7 \cdot 2$. Owing to the presence of both positively charged ions and hydrophobic ethoxyl groups, the glass is considered to be amphipathic. Three other types of surface-modified glass slides were prepared from aminopropyl glass by forming Schiff's bases with three aldehydes: glucose, glyoxylic acid and hexanal. The aldehyde-treated slides were subsequently reduced using sodium borohydride. Thus, the surface of the glass was rendered hydrophilic, ampholytic or hydrophobic, respectively. The adherence of two Streptococcus sanguis strains and two Streptococcus mutans strains to the surface-modified glass slides was studied. Different strains showed differences in adherence to these slides depending on their physico-chemical surface properties. For $S$. sanguis ATCC 10556, hydrophobic bonds seemed to be most important, while in $S$. mutans OMZ 176, ionic interactions made the highest contribution to adhesion. Hydrogen bonds seemed to contribute least to adherence.

\section{INTRODUCTION}

Bacterial adherence to dental materials has been extensively studied (Rutter \& Vincent, 1980; Gibbons \& Van Houte, 1980). Some authors have attributed adherence to electrostatic forces (O'Brien et al., 1978; Onose et al., 1980; Larsson \& Glantz, 1981; Reynold \& Wong, 1983), while others have attributed it to hydrophobic interactions (Nesbitt et al., 1982; Busscher et al., 1984; Weerkamp et al., 1985; Van Pelt et al., 1985). A thermodynamic model was developed to establish a correlation between surface free energy and bacterial adherence on hydrophobic surfaces, assuming a constant contribution of electrostatic forces (Gerson, 1980). However, studies of the adherence of oral bacteria to dental prosthetics or restoratives have shown that the electrostatic contribution may vary from species to species. Furthermore, some authors have used gold plate as an electrode to which bacteria were attached (Onose et al., 1980), while others used dental prosthetics as substrates (Minagi et al., 1985). The use of such a variety of substrates has prevented the direct comparison of the relative contributions of individual physico-chemical forces to the adherence of oral bacteria to prosthetics or restoratives.

To study the mechanism of bacterial adherence to solid surfaces, the experimental system must be simplified so that the relative contribution of the various chemical and physical forces can be assessed. In this work, we prepared glass slides having various organic functional groups on the surface, such as amino, carboxyl, hydroxyl or hydrophobic groups attached through the covalent bond between silicon and carbon. Measuring the adherence of oral bacteria to these slides allowed a comparison of the relative contributions to adherence made by various physicochemical forces.

\footnotetext{
Abbreviations: AmP-glass, aminopropyl glass; GA-, GL- and HA-glass, AmP-glass modified by conjugation with glyoxylic acid, D-glucose and hexanal, respectively (see text).
} 


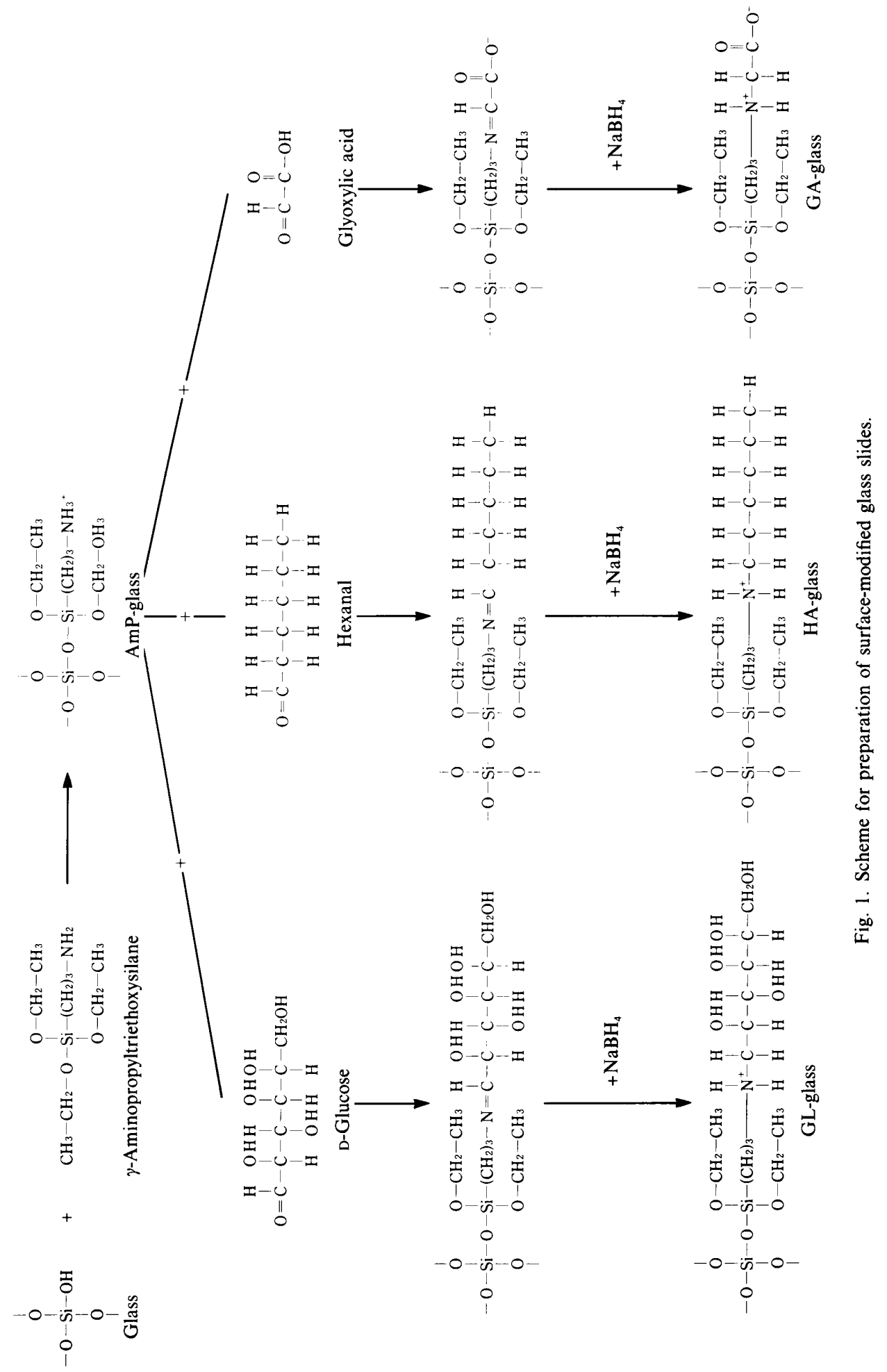


Table 1. Contact angles of distilled water on surface-modified glass slides

The values are means of 36 determinations \pm SD.

$\begin{array}{lc}\text { Modified glass } & \text { Contact angle } \\ \text { GL-glass } & 48 \cdot 8 \pm 6.0 \\ \text { HA-glass } & 75 \cdot 1 \pm 1.6 \\ \text { AmP-glass } & 69.5 \pm 0.6 \\ \text { GA-glass } & 46.6 \pm 3.5\end{array}$

\section{METHODS}

Preparation of aminopropyl (AmP) glass. Glass slides (Matunami Garasu Co., Kyoto, Japan) were immersed in potassium dichromate/sulphuric acid for $2 \mathrm{~h}$, rinsed with running water, washed twice with distilled water and dried. The slides were then immersed in $10 \mathrm{M}-\mathrm{NaOH}$ for $24 \mathrm{~h}$. After washing as described above, they were dried at $500{ }^{\circ} \mathrm{C}$ for $5 \mathrm{~h}$. The slides were then treated with $4 \%(\mathrm{v} / \mathrm{v}) \gamma$-aminopropyltriethoxysilane in acetone at $45^{\circ} \mathrm{C}$ for $24 \mathrm{~h}$ according to the method described by Robinson et al. (1971) and Baum et al. (1972). After completion of the reaction, the slides were washed with acetone to remove excess reagent, air-dried and stored in a desiccator (these slides are referred to as AmP-glass). Since the primary amino groups may associate with protons at $\mathrm{pH} 7 \cdot 2$, the surface of AmP-glass may have a positive charge, and therefore be partially hydrophilic at this $\mathrm{pH}$. However, since the rest of the $\gamma$-aminopropyldiethoxysilyl groups may be hydrophobic, AmP-glass is considered to be amphipathic. To estimate the amount of aminopropyl groups attached to AmP-glass slides, they were treated with 2,4,6-trinitrobenzenesulphonic acid (Cuatrecasas, 1970). The AmP-glass produced an orange colour product. The trinitrophenylated AmP-glass was cut into smaller pieces, which were put into a cuvette (light path $1 \mathrm{~cm}$ ). The cuvette was filled with distilled water to make a final volume of $3 \mathrm{ml}$. The absorbance at 345 or $420 \mathrm{~nm}$ was determined against distilled water. The total amount of chromophore was calculated from the molar absorbancy index of trinitrophenylated glycine $\left(6.51 \times 10^{3} \mathrm{~cm}^{-1} \mathrm{M}^{-1}\right.$ at $420 \mathrm{~nm}$ and $14.1 \times 10^{3} \mathrm{~cm}^{-1} \mathrm{M}^{-1}$ at $345 \mathrm{~nm}$ : Mokrasch, 1967). By dividing the total amount by the surface area of AmP-glass, a value of $1.49 \times 10^{-3} \mu \mathrm{mol} \mathrm{cm}^{-2}$ for the coverage of amino groups per $\mathrm{cm}^{2}$ on AmP-glass was obtained (it was assumed that aminopropyl groups on AmP-glass were in a monomolecular layer). Additional corroboration for the alteration of the glass surface was obtained by comparing the contact angle of water on the modified glass $\left(69 \cdot 5^{\circ}\right.$; see Table 1$)$ with that on untreated glass $\left(25 \cdot 2^{\circ}\right)$.

Conjugation of glyoxylic acid, hexanal and D-glucose to AmP-glass. AmP-glass slides were treated with $5 \%(\mathrm{w} / \mathrm{v})$ glyoxylic acid in distilled water, $5 \%(\mathrm{v} / \mathrm{v})$ hexanal in tetrahydrofuran, or $5 \%(\mathrm{w} / \mathrm{v}) \mathrm{D}-\mathrm{glucose}$ in distilled water at room temperature for $2 \mathrm{~h}$. After completion of the reactions, excess reagents were removed by washing with a large amount of distilled water (or, in the case of hexanal treatment, with absolute tetrahydrofuran and water), followed by treatment with $0.4 \%$ sodium borohydride in distilled water for $24 \mathrm{~h}$ at room temperature to reduce the imino group to the more stable amino group. The surface-modified slides so produced were washed with distilled water and used for the adherence assay. The modified slides thus formed are referred as GA-glass, HA-glass, GL-glass, respectively (Fig. 1), and their surface properties were ampholytic (hydrophilic), hydrophobic and hydrophilic, respectively. The concentrations of the attached groups (glucose, hexanal and glyoxylic acid residues) were not determined, since no convenient method to estimate these residues was available. Instead, the contact angle of water on each surface-modified glass was measured so as to judge whether the conjugation reaction had been successful (Table 1). The contact angle on HA-glass was higher than that on any of the other surface-modified glasses tested, consistent with the hydrophilic group in AmP-glass $\left(-\mathrm{NH}_{3}^{+}\right)$having been converted into a more hydrophobic hexylamino group. A similar conclusion was reached for GA-glass. The lower contact angle for GAglass than that for AmP-glass was consistent with the hydrophilic nature of the added ligand (glyoxylic acid). From these results it appeared that the Schiff's base forming reaction was at least partially successful.

Organisms and culture conditions. Streptococcus sanguis ATCC 10556, S. sanguis ATCC 10557, S. mutans OMZ 176 and $S$. mutans Ingbritt were used. All strains were grown in trypticase soy broth (BBL Microbiology Systems) supplemented with $0.5 \%$ yeast extract. The cells were harvested during the exponential growth phase by centrifugation at $1000 \mathrm{~g}$ at $4{ }^{\circ} \mathrm{C}$ for $15 \mathrm{~min}$, and washed twice with $0.05 \mathrm{M}$-Tris/HCl buffer (pH 7.2). The washed bacteria were suspended in the same buffer. The cell suspensions were subjected to low-intensity ultrasonic treatment in tubes held on crushed ice, to disperse bacterial chains and aggregates (Stinson et al., 1982). Generally, $40 \mathrm{~s}$ of minimum-intensity ultrasound was sufficient to produce predominantly single cells and pairs (Stinson $e t$ al., 1982). Cell suspensions were immediately used for the experiment to avoid reaggregation. The optical densities of the suspensions were measured in a $3 \mathrm{ml}$ cuvette with a $1 \mathrm{~cm}$ light path, using a Hitachi model 100-50 spectrophotometer, and the suspensions were adjusted to give an $\mathrm{OD}_{550}$ of $0.3\left(3.65 \times 10^{8} \mathrm{cells}^{-1}\right)$. 
Adherence test. Six slides of each surface-modified glass (all prepared from AmP-glass made at one time) were placed in a beaker, making a circle round the central area occupied by a magnetic stirring rod. Bacterial suspensions were poured into the beaker and stirred gently for $2 \mathrm{~h}$ at $37^{\circ} \mathrm{C}$. Each slide was taken out, washed with $50 \mathrm{ml}$ distilled water in a beaker, fixed with $2.5 \%(\mathrm{v} / \mathrm{v})$ glutaraldehyde at $4{ }^{\circ} \mathrm{C}$ for $30 \mathrm{~min}$, and stained with $1 \%$ $(\mathrm{w} / \mathrm{v})$ acridine orange. The numbers of adherent bacteria were obtained by counting bacteria directly under a fluorescence microscope (Olympus model BHS) according to the method described by Ørstavik et al. (1974). The numbers of bacteria in each of 20 separate fields were counted for every slide and divided by the area of the field. From the values thus obtained the average number of cells per $\mathrm{mm}^{2}$ of glass-surface was calculated. The mean values of these averages, obtained from six replicate slides of each surface-modified glass, were calculated with their standard errors. All the numerical data obtained were subjected to Student's $t$-test at the $1 \%$ and $5 \%$ levels. Each strain was tested four times in this system.

Determination of contact angle. The contact angles of distilled water on the four types of surface-modified glass were measured by the horizontal projection technique with a contact-angle meter (model CA-A; Kyowa Co., Tokyo, Japan) at $20^{\circ} \mathrm{C}$ and at six separate points on six slides of each type of modified glass.

To measure the contact angle of streptococci, a streptococcal layer was prepared on membrane filter (pore size $0.45 \mu \mathrm{m}$; Millipore) from $10 \mathrm{ml}$ of bacterial suspension with an $\mathrm{OD}_{550}$ of $1.0\left(10^{10}\right.$ cells per $\left.10 \mathrm{ml}\right)$. The filter carrying the streptococcal layer was air-dried for $120 \mathrm{~min}$ (Busscher et al., 1984), and the contact angle of water was measured by the same method as that for surface-modified glass.

Determination of zeta potential. Bacterial suspensions were prepared as described above. Electrophoresis was performed at the so-called stationary level in a particle micro-electrophoresis apparatus, using a flat glass cell and platinum electrodes (Olsson et al., 1976). The voltage used was $10 \mathrm{~V}$. The electrokinetic potential $(\zeta)$ was calculated from the Helmholtz-Smoluchowski formula (Davies \& Rideal, 1963): $\zeta=4 \pi \eta U / D$, where $U$ is the electrophoretic mobility or velocity at unit potential gradient, $\eta$ is the viscosity of the liquid, and $D$ is the dielectric constant.

\section{RESULTS}

Effect of time on adherence of bacteria to AmP-glass. The adherence assay was carried out for varying time periods. The numbers of bacteria adhering to each kind of glass increased with time until they reached a saturation level which was specific for each type of glass (Fig. 2). After $2 \mathrm{~h}$ the numbers of bacteria adhering remained constant. In all the following experiments $2 \mathrm{~h}$ incubations were used.

Adherence of streptococcal strains to the various surface-modified glasses. Table 2 shows the results obtained by incubating the two $S$. sanguis strains and two $S$. mutans strains with the four different kinds of surface-modified glass. The numbers of bacteria adhering varied, depending on the type of surface-modified glass. $S$. sanguis ATCC 10556 adhered in highest numbers to HA-glass and in lowest numbers to GL-glass $(P<0.01)$. There was no significant difference between its adherence to GA-glass and to GL-glass. With $S$. sanguis ATCC 10557 no such difference between HA-glass and GL-glass was observed, suggesting that different strains of a single species of bacteria may have different surface properties. In contrast, both $S$. mutans strains showed the highest adherence capacity to AmP-glass of the four types of surfacemodified glass, suggesting an important contribution of electrostatic force in adherence of these strains. Although both $S$. mutans strains adhered to HA-glass, there was a significant difference $(P<0.01)$ in their affinity for this glass, suggesting that the relative contribution of hydrophobic bonds might be different between these two strains.

Contact angles of the streptococcal strains. The contact angles of water droplets on dried bacterial surfaces for the four strains (means $\pm \mathrm{SD}, n=10$ ) were: $S$. sanguis ATCC 10556, 37.2 ${ }^{\circ}$ $\pm 1.4^{\circ} ; S$. sanguis ATCC $10557,44.1^{\circ} \pm 2 \cdot 8^{\circ} ; S$. mutans OMZ 176, 32.0 ${ }^{\circ} \pm 0.8^{\circ} ; S$. mutans Ingbritt, $15 \cdot 8^{\circ} \pm 2 \cdot 2^{\circ}$.

$\zeta$-potentials of the streptococcal strains. Although the $\zeta$-potentials of many oral bacteria were studied by Olsson et al. (1976), they were determined using a different buffer and $\mathrm{pH}$ from those adopted in this experiment. To correlate the present adhesion and contact-angle results with the $\zeta$-potentials of the bacteria, we thus determined the $\zeta$-potentials under the conditions used for our experiments. The $\zeta$-potentials of the four strains fell in a range between -21 and $-32 \mathrm{mV}$ (Table 3), values consistent with those measured by Olsson et al. (1976). The less negative $\zeta-$ 


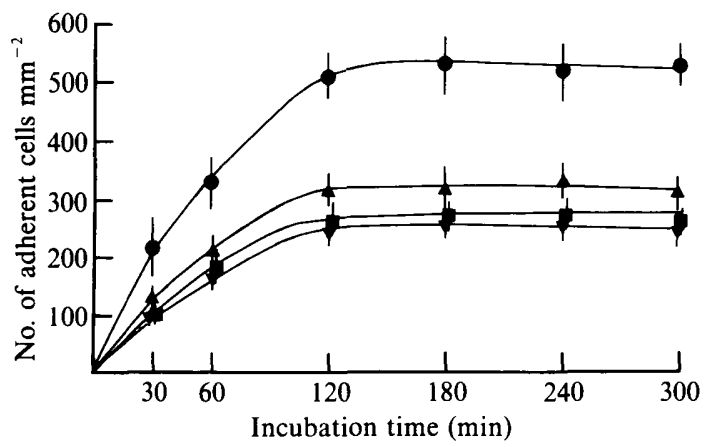

Fig. 2. Effect of time on adherence of $S$. sanguis ATCC 10556 to surface-modified glass ( $\mathbf{A}$, AmP-glass; $\square$, GA-glass; $\boldsymbol{\nabla}$, GL-glass; , HA-glass). Vertical lines indicate standard deviations obtained from six replicate glass slides.

Table 2. Adherence of oral streptococci to various surface-modified glass slides

The values indicate the mean number $\left( \pm \mathrm{SE}\right.$ ) of bacteria adhered per $1 \mathrm{~mm}^{2}$ of various surface-modified glass slides (the values were obtained from six replicate slides, for each of which the number of bacteria adhered in 20 separate views was counted and the mean number of bacteria adhered per $\mathrm{mm}^{2}$ was calculated). Differences between the values indicated by the same letter are significant at the $5 \%$ level $(c, e, s, v, w)$ or the $1 \%$ level $(a, b, d, f, g, h, k, t)$.

$\begin{array}{lcccc}\begin{array}{c}\text { Modified } \\ \text { glass }\end{array} & \begin{array}{c}\text { S. sanguis } \\ \text { ATCC } 10556\end{array} & \begin{array}{c}\text { S. sanguis } \\ \text { ATCC } 10557\end{array} & \begin{array}{c}\text { S. mutans } \\ \text { OMZ } 176\end{array} & \begin{array}{c}\text { S. mutans } \\ \text { Ingbritt }\end{array} \\ \text { GL-glass } & 132 \pm 4^{a} & 593 \pm 20^{e} & 353 \pm 15^{f g} & 256 \pm 25^{t v} \\ \text { HA-glass } & 485 \pm 35^{a b} & 613 \pm 11^{d} & 582 \pm 44^{\text {hs }} & 367 \pm 32^{v} \\ \text { AmP-glass } & 210 \pm 21^{a c} & 571 \pm 16 & 760 \pm 42^{k g} & 418 \pm 25^{\text {tw }} \\ \text { GA-glass } & 150 \pm 8^{b c} & 521 \pm 16^{\text {de }} & 404 \pm 23^{k h} & 295 \pm 29^{w}\end{array}$

Table 3. Electrophoretic mobility (towards the anode) and $\zeta$-potential of oral streptococci in Tris/ $\mathrm{HCl}$ buffer $\left(0.05 \mathrm{M}, \mathrm{pH} \mathrm{7.2)}\right.$ at $25^{\circ} \mathrm{C}$

Strain

S. sanguis ATCC 10556

S. sanguis ATCC 10557

S. mutans OMZ 176

$S$. mutans Ingbritt
Electrophoretic mobility*

$$
\left(\mu \mathrm{m} \mathrm{cm} \mathrm{s} \mathrm{V}^{-1}\right)
$$

$$
\begin{array}{ll}
1.89 \pm 0.29 & -24.4 \\
1.66 \pm 0.18 & -21.4 \\
2.42 \pm 0.20 & -31.0 \\
2.46 \pm 0.13 & -31.7
\end{array}
$$

* The mean values and standard deviations of each strain were calculated from the mobilities of 10 cells in two directions measured on five occasions.

† Calculated from the mean electrophoretic mobilities according to the Helmholtz-Smoluchowski formula.

potentials of the two strains of $S$. sanguis as compared with the two $S$. mutans strains is consistent with the data on contact angles, where $S$. sanguis showed larger contact angles (more hydrophobic) than $S$. mutans.

\section{DISCUSSION}

When the aldehyde group of hexanal was used to make a Schiff's base link with the amino group of AmP-glass, the surface of the resultant HA-glass seemed to be rendered more hydrophobic due to the introduction of the hexyl group. The $S$. sanguis strains showed the highest affinity to HA-glass, suggesting that hydrophobic bonds play an important role in their 
adherence, although the extent of the contribution may vary according to the nature of the bacterial cell surface. Thus, in $S$. sanguis ATCC 10556 hydrophobic bonds seemed to make the largest contribution, while in $S$. mutans Ingbritt they seemed to contribute to a lesser extent. This is consistent with the observation that $S$. sanguis ATCC 10556 showed a high contact angle (indicating a highly hydrophobic surface), whereas $S$. mutans Ingbritt showed much lower contact angle (indicating a less hydrophobic surface).

AmP-glass possesses positively charged groups $\left(-\mathrm{NH}_{3}^{+}\right)$and $\mathrm{GA}$-glass possesses both negatively charged $\left(-\mathrm{COO}^{-}\right)$and positively charged $\left(-\mathrm{NH}_{2}^{+}\right)$groups. The fact that AmP-glass showed a higher adherence capacity for $S$. mutans than GA-glass is consistent with the strongly negative $\zeta$-potentials found for $S$. mutans. The generally lower adherence to GA-glass than to AmP-glass could be due to the repulsive force between the negative charges on the GA-glass and the bacterial surface.

The fact that for the two strains of $S$. mutans, the numbers of bacteria adhering to AmP-glass were higher than those adhering to HA-, GA- and GL-glasses suggests that electrostatic interaction may be important in the adherence of these strains. Conversely, the lower adherence of $S$. sanguis ATCC 10556 to AmP-glass than to the other types of glass tested suggests that in this strain electrostatic interactions contribute to a lesser extent than hydrophobic interactions. From these results it may be concluded that in $S$. sanguis hydrophobic interactions play a more important role than electrostatic forces, while in $S$. mutans the reverse is true.

GL-glass showed the lowest adherence capacity for all the bacteria tested except $S$. sanguis ATCC 10557. Since the carbonyl group of glucose was used to make the Schiff's base link, the surface of the resultant GL-glass was rendered much more hydrophilic by the addition of pentahydroxymethylene residues. The hydroxyl group possesses a strong capacity to form hydrogen bonds if there are acceptors or donors present. Water molecules may function as acceptors or donors, and a strong interaction between GL-glass and water molecules may have prevented the adherence of bacterial cells.

From these results, it may be concluded that neither electrostatic forces alone nor hydrophobic interactions alone determine the adherence of $S$. sanguis and $S$. mutans to modified glass.

Since the method presented here is a model, the results obtained may not be directly applicable to bacterial adherence in the oral cavity. However, studies with glass surfaces covalently modified with hydrophobic, hydrophilic, and/or charged groups provide a useful technique for estimating the relative strengths of physico-chemical forces working on nonspecific bacterial adherence, and may be applied to the development of materials resistant to bacterial adherence.

\section{REFERENCES}

Baum, G., Ward, F. B. \& Weettall, H. H. (1972). Stability, inhibition and reactivation of acetylcholinesterase covalently coupled to glass. Biochimica et biophysica acta 268, 411-414.

Busscher, H. J., WeERKamp, A. H., Van der Mei, H. C., Van Pelt, A. W. J., De Jong, H. P. \& ARENDS, J. (1984). Measurement of the surface free energy of bacterial cell surfaces and its relevance for adhesion. Applied and Environmental Microbiology 48, 980-983.

Cuatrecasas, P. (1970). Protein purification by affinity chromatography. Journal of Biological Chemistry 245, 3059-3065.

Davies, J. T. \& Rideal, E. K. (editors) (1963). Interfacial Phenomena. New York: Academic Press.

Gerson, D. F. (1980). Cell surface energy, contact angles and phase partition-lymphocytic cell lines in biphasic aqueous mixtures. Biochimica et biophysica acta 602, 269-280.

Gibbons, R. J. \& VAN Houte, J. (1980). Bacterial adherence and the formation of dental plaque. In
Bacterial Adherence, Receptors and Recognition, series B, vol. 6, pp. 61-104. Edited by E. H. Beachey. New York \& London: Chapman \& Hall.

Larsson, K. \& Glantz, P. O. (1981). Microbial adhesion to surfaces with different surface charges. Acta odontologica scandinavica 39, 79-82.

Minagi, S., MiYake, Y., Inagaki, K., Tsuru, H. \& SugINAKA, H. (1985). Hydrophobic interaction in Candida albicans and Candida tropicalis adherence to various denture base resin materials. Infection and Immunity 47, 11-14.

MoKRASCH, L. C. (1967). Use of 2,4,6-trinitrobenzenesulfonic acid for the coestimation of amines, amino acids, and proteins in mixtures. Analytical Biochemistry 18, 64-71.

NeSBitT, W. E., Doyle, R. J. \& TAYLOR, K. G. (1982). Hydrophobic interactions and the adherence of Streptococcus sanguis to hydroxyapatite. Infection and Immunity 38, 637-644.

O'Brien, W. J., FAN, P. L., Loesche, W. J., W Alker, M. C. \& APOSTOLIDS, A. (1978). Adsorption of 
Streptococcus mutans on chemically treated hydroxyapatite. Journal of Dental Research 57, 910-914.

Olsson, J., Glantz, P. O. \& Krasse, B. (1976).

Electrophoretic mobility of oral streptococci. $A r$ chives of Oral Biology 21, 605-609.

Onose, H., MiYazaki, T. \& Nomoto, S. (1980). Effect of electrical potential on the adherence of Streptococcus sanguis to gold plate. Journal of Dental Research 59, 1179.

Ørstavik, D., Krause, F. W. \& Henshaw, L. C. (1974). In vitro attachment of streptococci to the tooth surface. Infection and Immunity 9, 794-800.

ReYNOLD, E. C. \& WoNG, A. (1983). Effect of absorbed protein on hydroxyapatite zeta potential and Streptococcus mutans adherence. Infection and Immunity 39, 1285-1290.

Robinson, P. J., DunNill, P. \& Lilly, M. D. (1971). Porous glass as a solid support for immobilisation or affinity chromatography of enzymes. Biochimica et biophysica acta 242, 659-661.

RUTTER, P. R. \& VINCENT, B. (1980). The adhesion of microorganisms to surfaces: physico-chemical aspects. In Microbial Adhesion to Surfaces, pp. 79-92. Edited by R. C. W. Berkeley, J. M. Lynch, J. Melling, P. R. Rutter \& B. Vincent. Chichester: Ellis Horwood.

Stinson, M. W., Levine, M. J., Cavese, J. M., Prakobphol, A., Murray, P. A., Tabak, L. A. \& REDDY, M. S. (1982). Adherence of Streptococcus sanguis to salivary mucin bound to glass. Journal of Dental Research 61, 1390-1393.

Van Pelt, A. W. J., Weerkamp, A. H., Uyen, M. H. W. J. C., BusscheR, H. J., De JoNG, H. P. \& ARENDS, J. (1985). Adhesion of Streptococcus sanguis $\mathrm{CH} 3$ to polymers with different surface free energies. Applied and Environmental Microbiology 49, 12701275.

Weerkamp, A. H., Van Der Mei, H. C. \& Busscher, H. J. (1985). The surface free energy of oral streptococci after being coated with saliva and its relation to adhesion in the mouth. Journal of Dental Research 64, 1204-1210. 